\title{
New technique for servo-control of arterial oxygen tension in preterm infants
}

\author{
I. R. BEDDDIS, P. COLLINS, N. M. LEVY, S. GODFREY, AND M. SILVERMAN \\ Departments of Paediatrics and Neonatal Medicine, and Medical Physics, Hammersmith Hospital, London
}

SUMMARY Equipment has been developed for the servo-control of arterial oxygen tension in sick, newborn babies. Using an indwelling umbilical arterial oxygen electrode as sensor, the equipment successfully regulated the administration of oxygen to 12 newborn babies with respiratory distress syndrome, significantly improving the stability of arterial oxygen tension and lessening the duration of episodes of hypoxia and hyperoxia.

In recent years, the continuous monitoring of oxygen tension in sick, preterm babies has been made possible by the development of miniature polarographic electrodes. Arterial oxygen tension $\left(\mathrm{PaO}_{2}\right)$ can be measured using an umbilical cathetertip electrode, or transcutaneously using a heated skin-surface electrode. Thus, the twin hazards of prolonged hypoxia (Stewart and Reynolds, 1974), and hyperoxia (Ashton et al., 1953), can be avoided by manual adjustments to the fractional inspired oxygen concentration $\left(\mathrm{F}_{\mathrm{I}} \mathrm{O}_{2}\right)$ when $\mathrm{PaO}_{2}$ deviates from within safe limits.

When $\mathrm{PaO}_{2}$ is continuously monitored in sick, preterm babies, pronounced fluctuations can be seen to occur within short periods of time, although intermittent blood-gas analysis may indicate a steady state. Fluctuations may occur spontaneously, or result from routine nursing or other procedures (Speidel, 1978), and such changes in $\mathrm{PaO}_{2}$ together with alterations in heart rate and blood pressure may be responsible for intracranial haemorrhage in some cases (Wigglesworth and Pape, 1978). Correction of these fluctuations by the manual adjustment of $\mathrm{F}_{\mathrm{I}} \mathrm{O}_{2}$ requires constant, time-consuming observation. It seemed obvious to try to automate this procedure

Hammersmith Hospital, London

Department of Paediatrics and Neonatal Medicine

I. R. BEDDIS, research fellow

M. SILVERMAN, senior lecturer

Department of Medical Physics

P. Collins, electronics engineer

Department of Medical Engineering

N. M. LEVY, scientific instrument maker

Department of Paediatrics, Hadassah University Hospital,

Mount Scopus, Jerusalem, Israel

S. GODFREY, professor of paediatrics and we describe the application of a prototype machine for the automatic control of $\mathrm{PaO}_{2}$ in sick, preterm babies.

\section{Patients and methods}

12 preterm babies with respiratory distress syndrome were studied in the first week of life. Their birthweights ranged between 760 and $2260 \mathrm{~g}$ (mean 1640) with gestational ages between 26 and 34 weeks (mean 31-3). The main items of equipment and their arrangement are shown in the Figure.

In each case, $\mathrm{PaO}_{2}$ and $\mathrm{F}_{1} \mathrm{O}_{2}$ were continuously monitored using an indwelling umbilical artery catheter-tip electrode (Searle) and an oxygen analyser (Hudson). The umbilical catheter was continuously flushed with dextrose/saline at a rate of $0.5 \mathrm{ml} /$ hour. Its reading was checked at least 4-hourly by formal blood-gas analysis (I.L. 213 blood-gas analyser), and adjustments were made as necessary. The largest adjustment required during the study period was $1.6 \mathrm{kPa}(12 \mathrm{mmHg})$.

The output of the $\mathrm{PaO}_{2}$ electrode was fed into the servo-control unit, the technical details of which are

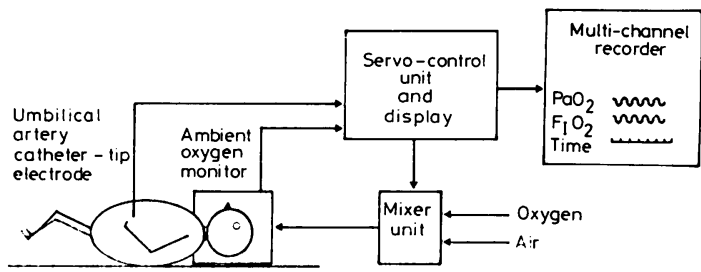

Figure Arrangement of apparatus and equipment. 
presented in a separate paper (Collins et al., 1979). At 1-min intervals, the reading was compared with the preset limits for $\mathrm{PaO}_{2}$ : lower limit $7 \cdot 3 \mathrm{kPa}$ (55 $\mathrm{mmHg})$, upper limit $10.7 \mathrm{kPa}(80 \mathrm{mmHg})$. If the $\mathrm{PaO}_{2}$ was outside these limits, the servo-control unit adjusted the $\mathrm{F}_{\mathrm{IO}_{2}}$ (by means of a $\mathrm{BOC}$ air/oxygen mixer tap) by a single step of $5 \%$. Thus, automatic adjustments of $\mathrm{FIo}_{2}$ were made at 1-min intervals if necessary. If 3 successive steps (i.e. $15 \%$ change in oxygen requirements) in either direction occurred, alarms were activated. Any defect developing in the function of the catheter-tip electrode would cause such successive steps in $\mathrm{F}_{\mathrm{I}} \mathrm{O}_{2}$ to be made, and would therefore lead to activation of the alarms. Thus, the alarm would indicate failure of the equipment, disconnection of tubing supplying oxygen to the infant, or a change in the clinical state of the baby-such as a pneumothorax. In the event of mains failure, a preset $\mathrm{F}_{1} \mathrm{O}_{2}$ would continue to be provided and in an emergency any desired $\mathrm{F}_{\mathrm{I}} \mathrm{O}_{2}$ could be obtained by pressing a button.

Using a multichannel chart recorder (Devices), $\mathrm{PaO}_{2}$ and $\mathrm{F}_{1} \mathrm{O}_{2}$ were continuously recorded during the study. The first 9 babies were monitored during alternate 4- to 6-hour periods and the final 3 babies on random 4-hourly periods on servo-control or on manual control by the nurse, who adjusted the $\mathrm{F}_{\mathrm{IO}}$ if necessary. Oxygen was given according to clinical indications, by headbox or face mask or by endotracheal tube during the application of continuous positive airway pressure (CPAP) or during intermittent positive pressure ventilation (IPPV). The number of occasions during which the $\mathrm{PaO}_{2}$ was outside the set limits and the duration of each occasion was calculated for each control period for different methods of oxygen administration to each baby. Paired $t$ tests were used to determine the significance of differences between servo- and manual-control periods.

\section{Results}

The percentage of time spent outside the set limits of $\mathrm{PaO}_{2}$ for each method of oxygen administration during servo-control and manual-control periods, is shown in the Table. The overall difference between servo-control and manual-control periods was highly significant $(t=6.36 ; \mathrm{P}<0 \cdot 001)$. The proportion of time during which $\mathrm{PaO}_{2}$ was below the lower set limit was also significantly less on servocontrol than on manual-control $(t=4 \cdot 48$; $\mathbf{P}<0 \cdot 001)$. However, there was no significant difference between servo- and manual-control periods when the percentage of time above the upper set limits was compared $(t=1 \cdot 87 ; \mathrm{P}=0 \cdot 08)$.

In 11 of 12 babies the percentage of time outside the limits was less with the servo-control; in the 12th baby, the percentage was equal. Overall the $\mathrm{PaO}_{2}$ was outside the set limits for $12 \cdot 2 \%$ of the time when on servo-control and for $27.6 \%$ of the time when on manual-control.

The number of episodes during which the $\mathrm{PaO}_{2}$ was $<7.3 \mathrm{kPa}$ and $>10.7 \mathrm{kPa}$ in the respective periods is also shown in the Table. The $\mathrm{PaO}_{2}$ was below the set range on 263 occasions on servocontrol and on 267 occasions on manual-control, and was above the upper set limit on 236 and 178 occasions respectively.

The mean duration of each episode below the lower limit on servo-control was $2.5 \mathrm{~min}$ and on manual-control it was $6 \cdot 1 \mathrm{~min}$. For the 12 patients, the difference in mean duration was highly significant $(t=6 \cdot 51 ; \mathrm{P}=<0 \cdot 001)$. The mean duration of each episode above the upper limit on servo-

Table Comparison of servo-control and manual-control periods

\begin{tabular}{|c|c|c|c|c|c|c|c|c|c|c|}
\hline \multirow{2}{*}{$\begin{array}{l}\text { Method of } \\
\text { oxygen } \\
\text { administration }\end{array}$} & \multirow[t]{2}{*}{$\begin{array}{l}\text { No. of } \\
\text { infants* }\end{array}$} & \multirow[t]{2}{*}{$\begin{array}{l}\text { Control } \\
\text { type }\end{array}$} & \multirow[t]{2}{*}{$\begin{array}{l}\text { Duration } \\
\text { (hours) }\end{array}$} & \multicolumn{3}{|c|}{$\begin{array}{l}\text { Percentage of time } \\
\text { outside set limits }\end{array}$} & \multicolumn{2}{|c|}{$\begin{array}{l}\text { No. of episodes } \\
\text { outside limits }\end{array}$} & \multicolumn{2}{|c|}{$\begin{array}{l}\text { Mean duration of episodes } \\
\text { outside limits (min) }\end{array}$} \\
\hline & & & & Low & High & Overall & Low & High & Low & High \\
\hline $\begin{array}{l}\text { Intermittent } \\
\text { positive } \\
\text { pressure } \\
\text { ventilation }\end{array}$ & 5 & $\begin{array}{l}\text { Servo } \\
\text { Manual }\end{array}$ & $\begin{array}{l}74 \\
76 \cdot 5\end{array}$ & $\begin{array}{r}8 \cdot 2 \\
17 \cdot 7\end{array}$ & $\begin{array}{r}6 \cdot 4 \\
11 \cdot 2\end{array}$ & $\begin{array}{l}14 \cdot 6 \\
28 \cdot 9\end{array}$ & $\begin{array}{l}145 \\
126\end{array}$ & $\begin{array}{l}147 \\
107\end{array}$ & $\begin{array}{l}2 \cdot 5 \\
6 \cdot 5\end{array}$ & $\begin{array}{l}1 \cdot 9 \\
4 \cdot 8\end{array}$ \\
\hline $\begin{array}{l}\text { Continuous } \\
\text { positive } \\
\text { airway } \\
\text { pressure }\end{array}$ & 3 & $\begin{array}{l}\text { Servo } \\
\text { Manual }\end{array}$ & $\begin{array}{l}18 \\
18\end{array}$ & $\begin{array}{r}8 \cdot 2 \\
23 \cdot 3\end{array}$ & $\begin{array}{l}4 \cdot 2 \\
6 \cdot 1\end{array}$ & $\begin{array}{l}12 \cdot 4 \\
29 \cdot 4\end{array}$ & $\begin{array}{l}40 \\
42\end{array}$ & $\begin{array}{l}40 \\
22\end{array}$ & $\begin{array}{l}2 \cdot 2 \\
6 \cdot 0\end{array}$ & $\begin{array}{l}1 \cdot 1 \\
3 \cdot 0\end{array}$ \\
\hline Headbox & 6 & $\begin{array}{l}\text { Servo } \\
\text { Manual }\end{array}$ & $\begin{array}{l}53 \\
54 \cdot 5\end{array}$ & $\begin{array}{r}6 \cdot 4 \\
17 \cdot 3\end{array}$ & $\begin{array}{l}2 \cdot 6 \\
7 \cdot 8\end{array}$ & $\begin{array}{r}9 \cdot 0 \\
25 \cdot 1\end{array}$ & $\begin{array}{l}78 \\
99\end{array}$ & $\begin{array}{l}49 \\
49\end{array}$ & $\begin{array}{l}2 \cdot 6 \\
5 \cdot 7\end{array}$ & $\begin{array}{l}1 \cdot 7 \\
5 \cdot 2\end{array}$ \\
\hline Overall & 12 & $\begin{array}{l}\text { Servo } \\
\text { Manual }\end{array}$ & $\begin{array}{l}145 \\
149\end{array}$ & $\begin{array}{r}7 \cdot 5 \\
18 \cdot 3\end{array}$ & $\begin{array}{l}4 \cdot 7 \\
9 \cdot 3\end{array}$ & $\begin{array}{l}12 \cdot 2 \\
27 \cdot 6\end{array}$ & $\begin{array}{l}263 \\
267\end{array}$ & $\begin{array}{l}236 \\
178\end{array}$ & $\begin{array}{l}2 \cdot 5 \\
6 \cdot 1\end{array}$ & $\begin{array}{l}1 \cdot 7 \\
4 \cdot 7\end{array}$ \\
\hline
\end{tabular}

*Two babies were studied using more than one method of oxygen therapy. 
control was $1.7 \mathrm{~min}$ and on manual-control it was $4.7 \mathrm{~min}$. The difference in mean duration was significant for the 12 patients $(t=3 \cdot 85 ; \mathrm{P}=0 \cdot 002)$.

\section{Discussion}

This study shows that the servo-control of arterial $\mathrm{Po}_{2}$ is not only possible, but may also improve the stability of $\mathrm{PaO}_{2}$ in the newborn. The equipment has been used successfully to control the administration of oxygen by IPPV, CPAP, or headbox so that long periods of hypoxia or hyperoxia could be prevented.

The whole servo-control system obviously relies on the accuracy of the continuous-reading $\mathrm{PaO}_{2}$ electrode. So far, we have relied on umbilical arterial electrodes and we find that these give a satisfactory reading for a number of days, especially when flushed continuously at a low rate. There appears to be no reason why the system should not be used with a transcutaneous oxygen electrode. This would be particularly useful in the management of apnoea in preterm babies who often require a small increase in ambient oxygen, but who are particularly prone to episodes of hyperoxia with the attendant danger of retrolental fibroplasia. Whichever sensor is used, the need for regular, formal blood-gas analysis remains.

The range of $\mathrm{PaO}_{2}$ which we selected was 7.3-10 7 $\mathrm{kPa}$. The equipment had a 1 -min sampling interval and produced $5 \%$ changes in fractional inspired oxygen concentration. $10 \%$ steps were used during initial trials, but wide swings in $\mathrm{PaO}_{2}$ occurred. Neither the optimum sampling interval nor the size of stepwise changes in $\mathrm{F}_{\mathrm{I}} \mathrm{O}_{2}$ has been determined. The fact that the number of episodes during which the $\mathrm{PaO}_{2}$ was above the set limits was more on servocontrol than on manual-control, suggests that there may be room for improvement. Work is in progress to determine the optimum characteristics of the system for different methods of oxygen administration and for different clinical conditions.

We feel that the apparatus has a useful role to play in the management of preterm infants with respiratory problems, avoiding the necessity for constant observation of a $\mathrm{PaO}_{2}$ monitor and frequent manual adjustments of the fractional inspired oxygen concentration. The relative stability of $\mathrm{PaO}_{2}$ achieved by the servo-control equipment seems certain to contribute to a reduction in morbidity in sick newborn babies.

This project was carried out with the support of the Wellcome Foundation and with the help and advice of Professor V. Dubowitz and the late Professor R. Oliver.

\section{References}

Ashton, N., Ward, B., and Serpell, G. (1953). Role of oxygen in the genesis of retrolental fibroplasia. British Journal of Ophthalmology, 37, 513-520.

Collins, P., Levy, N. M., Beddis, I. R., Godfrey, S., and Silverman, M. (1979). Apparatus for the servo-control of arterial oxygen tension in preterm infants. Medical and Biological Engineering and Computing, in press.

Speidel, B. D. (1978). Adverse effects of routine procedures on preterm infants. Lancet, 1, 864-866.

Stewart, A. L., and Reynolds, E. O. R. (1974). Improved prognosis for infants of very low birthweight. Pediatrics, 54, 724-735.

Wigglesworth, J. S., and Pape, K. E. (1978). An integrated model for haemorrhagic and ischaemic lesions in the newborn brain. Early Human Development, 2, 179-199.

Correspondence to Dr I. R. Beddis, Department of Neonatal Medicine, Hammersmith Hospital, Du Cane Road, London W12 OHS.

Received 3 August 1978 